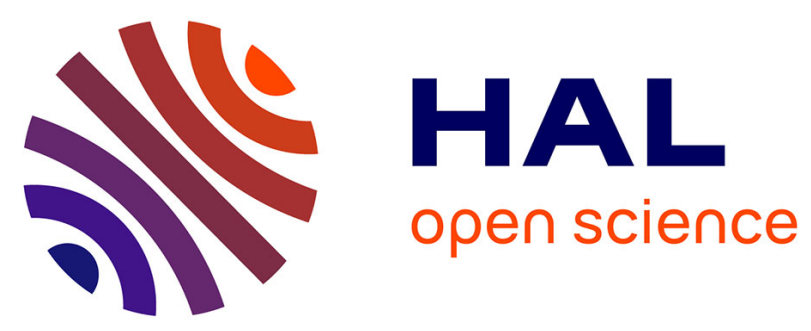

\title{
Coming back to a Commons approach to construct the Great Green Wall in Senegal
}

Etienne Delay, Abdou Ka, Khoudia Niang, Ibra Touré, Deborah Goffner

\section{To cite this version:}

Etienne Delay, Abdou Ka, Khoudia Niang, Ibra Touré, Deborah Goffner. Coming back to a Commons approach to construct the Great Green Wall in Senegal. Land Use Policy, 2022, 115, 10.1016/j.landusepol.2022.106000 . hal-03570432

\section{HAL Id: hal-03570432 \\ https://hal.science/hal-03570432}

Submitted on 13 Feb 2022

HAL is a multi-disciplinary open access archive for the deposit and dissemination of scientific research documents, whether they are published or not. The documents may come from teaching and research institutions in France or abroad, or from public or private research centers.
L'archive ouverte pluridisciplinaire HAL, est destinée au dépôt et à la diffusion de documents scientifiques de niveau recherche, publiés ou non, émanant des établissements d'enseignement et de recherche français ou étrangers, des laboratoires publics ou privés.

\section{(ㅇ)(1) $\$$}

Distributed under a Creative Commons Attribution - NonCommercial - NoDerivatives| 4.0 


\title{
Coming back to a Commons approach to construct the Great Green Wall in Senegal
}

\author{
Etienne Delay ${ }^{\mathrm{a}, \mathrm{b}, *}$, Abdou Ka ${ }^{\mathrm{c}, \mathrm{d}}$, Khoudia Niang $^{\mathrm{e}}$, Ibra Touréf,g, Deborah \\ Goffner ${ }^{\mathrm{i}, 1}$ \\ ${ }^{a}$ CIRAD UMR SENS, F-34398 Montpellier, France \\ ${ }^{b}$ UMR SENS, CIRAD, Université Cheikh Anta Diop, UCAD, Ecole Supérieure \\ Polytechnique, ESP, IRD, BP 15915, Dakar, Senegal \\ ${ }^{c}$ Université Assane Seck de Ziguinchor, UFR des Sciences Économiques et Sociales, \\ Département de Sociologie, B.P: 523, Ziguinchor - Sénégal \\ ${ }^{d}$ UMI 3189 Environnement, Santé, Sociétés (CNRS / UCAD/UGB / USTTB / CNRST) \\ ${ }^{e}$ Université Cheikh Anta Diop, Département de Biologie végétale, Faculté des Sciences et \\ Techniques, BP : 5005 Fann, Dakar, Sénégal \\ ${ }^{f}$ CIRAD, UMR SELMET, Campus International de Baillarguet, 34398 Montpellier, France \\ ${ }^{g}$ UMR SELMET, Université de Montpellier, CIRAD, INRA, Montpellier, France \\ ${ }^{h}$ Centre National de la Recherche Scientifique (CNRS)IRL 3189 Environnement, Santé, \\ Sociétés, 13015 Marseille, France/Université de Bamako, Mali/CNRST Burkina-Faso, \\ Université Cheikh Anta Diop, Dakar, Senegal \\ ${ }^{i}$ Stockholm Resilience Center (SRC), Stockholm University, 10405 Stockholm, Sweden
}

\begin{abstract}
Since the 1970s, the Sahel region has been struck by severe droughts that has brought suffering to human populations. Scientists also observed declining rainfall leading to desertification in the zone. Against this backdrop, in 2007, several African states launched the international Great Green Wall (GGW) project that aimed to create a strip of forest from Senegal to Djibouti, crossing areas mostly devoted to pastoralism. We examined the social, land tenure and environmental implications of the GGW in Senegal, in the light of policies for pastoral intensification of the zone. The colonial heritage of the foresters from the Senegalese National Green Wall Agency who implement the project on the ground influences how reforestation is managed today. To understand how local populations relate to the space affected by the project and their resources, we organized participatory workshops in four contrasted study sites along the Senegalese portion of the GGW path. Our results show that trees are of great importance for lo-
\end{abstract}

${ }^{*}$ Corresponding author 
cal populations, whether agricultural or pastoral, but even more so in pastoral areas. Despite this, the national and international narrative considers Sahelian pastoralism and overgrazing as strong drivers of desertification. The paradox is that overgrazing is linked to the public policy of boreholes densification. Taking a Commons approach, we show the current and past role played by water in pasture management, and how water accessed by boreholes no longer regulates grazing practices. A Commons approach would pave the way for assisting stakeholders at different levels to favour regreening the Sahel.

Keywords: Sahel, Great Green Wall, Commons, water management, water, forestry, pastoralism

2021 MSC: 04-02

\section{Introduction}

The concept of "desertification" emerged in the international community in the 1970s, but it was shaped 25 years prior to that. Elie (2015) traced the concept back to the early 1950s in the works of colonial agronomists and tropicalists.

5 Aubréville (1949) proposed this concept in association with savannisation to describe plant successions resulting from bush fires and the felling of vegetation by man, which were already devastating the tropical forests at that time in French colonial Africa.

Later, in 1968 and 1972, major droughts caused unprecedented famines in the Sahelian zone. The United Nations Assembly decided to "combat desertification" and launched a series of conferences (1977) which resulted in the gain

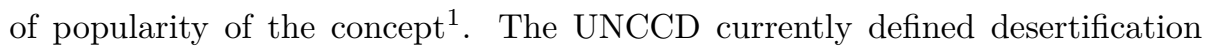
as: "land degradation in arid, semi-arid, and dry sub-humid areas resulting from various factors, including climatic variations and human activities, that is encompassing both biophysical and social factors" UNCCD) ([1994).

\footnotetext{
${ }^{1}$ UN General Assembly resolution 3337 (XXIX), 17 December 1974, 'International cooperation to combat desertification
} 
Up until the end of the 1980s, the GIMMS model showed a downward trend in plant cover at global scale ${ }^{\mathbb{\square}}$. The desertification process was directly linked to a reduction in rainfall available to plants, due to a southward shift in isohyets. These observations tallied with the results of foresight models, pointing to a global desertification trend (Le Howérnn, ए996).

More recently, the spatial shift of the concept of "desertification" from tropical forest areas to sub-Saharan and Sahelian areas has reinforced the false idea of desertification as an extension of the desert. In this interpretation, the problem in the Sahel is equated with that of the Sahara desert extending southward. tion of dunes, and less on issue of declining soil fertility, and ii) the image of advancing deserts promotes the idea that giant "green belts and walls" could "stop the desert".

Nevertheless, desertification is clearly a serious issue worldwide. Reynolds et al. (2007) note that $41 \%$ of the world's arable land is threatened by desertification and it poses a threat to 6.5 billion people. On the African continent Reich et al (200II) estimate that approximately $46 \%$ of the land is undergoing desertification, affecting roughly 485 million people. Face with increasing desertification over the past decades and supported by the international community, 35 eleven African states joined forces and in 2002, on World Desertification Day held in N'Djamena (Chad), they defined the common objective of establishing a Great Green Wall (GGW) in zones with less than $400 \mathrm{~mm}$ of rainfall per year. The project would involve "restoring" and planting a 7,675 km long forest strip from the coast of Senegal in the West to Djibouti in the East. The multinational project was officially launched in 2007 and the Pan-African Agency of the Great Green Wall (PAAGGW) was set up in 2010 to coordinate operations in the 11 participating countries (Dia and Duponnois, 2013). Seen from the Western world, the ambitions of the GGW are commendable and have provided increased visibility for the Sahelian zone (several articles on the topic

\footnotetext{
${ }^{2}$ GIMMS: Global Inventory Modeling and Mapping Studies, version 3 by Guay et al. (20115).
} 
were published in the French newspaper Le Monde, broadcast on France $24^{\mathbf{3}}$

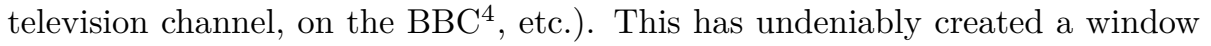
of opportunity for development actions (Goffner et al., 2010).

Herein, by specifically examining the GGW in Senegal in four contrasting sites, we show that the relationship between local populations and trees does not match with the narrative conveyed by national or international communities. By mobilizing a Commons approach (Committee, [2017), we are able to revisit the dynamics and socio-spatial issues of the area and see it as a confrontation between two contrasting perspectives: the first held by the former colonial State and in the continuity, the current modern State (through its forestry corps) and the second by local pastoral populations.

Finally, we propose an alternative to the ongoing top-down reforestation process, one in which authorities work more closely with local populations using community-based approaches. The community-based management idea was developed in the 1970s, but became more mainstream in 1992 at the Rio Earth Summit when the Commission on Sustainable Development recognized the role that local populations could play in resource management (Maraseni et al, 201.9). Herein we use a Community-based approaches one that is aligned with the French Land Tenure and Development Technical Committee. ${ }^{\text {. }}$

\footnotetext{
${ }^{3}$ Le Monde: 25 September 2012, 15 April 2016; reports on France 24 in August 2018, March 2019 , etc.

${ }^{4}$ BBC: 26 September 2017, 20 October 2019.

${ }^{5}$ The French Technical Committee "Land Tenure and Development" (Comité technique Foncier et Développement) is a group created in 1996 for debate and exchange on rural and urban land issues in Southern countries (Africa, Asia and Latin America), on the initiative of French Cooperation. It is co-chaired by the French Ministry of Europe and Foreign Affairs (MEAE) and the French Development Agency (AFD) http://www.foncier-developpement. fr/ consulted in Feb. 2021.
} 


\section{Background: the historical roots of the Great Green Wall gover- nance in Senegal}

In this section, we emphasize how the colonial legacy of the forest corps has created a paradoxical situation between its interventions that are aimed at reducing poverty and conserving biodiversity, while at the same time, often neglecting the real needs of local populations (Benjaminsen et al., 20018)

\subsection{The Senegalese National GGW Agency: A Colonial legacy}

Most current GGW staff are graduates of National Water and Forestry engineering schools. They carry a strong identity of their institution, which dates back to 1932. At that time, the colonial Water and Forestry service essentially replicated the Water and Forestry Corps of mainland France (Foury, [1953). Its original, overarching mission was to preserve forest areas, and more generally natural resources, with a vision of generating income ${ }^{\mathbf{t}}$. Like in mainland France, the Water and Forestry officers in Senegal also played a policing role in matters concerning natural resource management.

The Senegalese foresters have, however seen changes in their functions and prerogatives since Independence (1960). International aid donors encourage them to operate in "project mode", similar to that in development administrations. Indeed, projects provide attractive posts for those in charge of their implementation (remuneration, job security, means and ease of travel, etc.). Blundo and Sardan (200) underlined the attractiveness for forestry officers' positions as "posts with a high density of transactions, posts where there is direct contact with users, field posts rather than administrative posts".

In parallel with changes in the functions of the Water and Forestry service, the decentralization policies introduced in Senegal with the Domaine National

\footnotetext{
${ }^{6}$ Forests have been widely used for lumber, building timber, and firewood since the beginning of the 20th century (Bernard, 199.3)
} 
law $(1964)^{\mathbb{d}}$ led to natural resource management being entrusted to the muhave also affected local actors' accountability for natural resources. These institutional reforms all proceeded in the same direction, i.e., they attempt to increase the engagement of local actors in resource management policies. This led foresters to rethink their functions and operate less like a police authority

The Senegalese ANGGW clearly resonates with this more modern project logic. The Senegalese government was proactive in launching its GGW National Agency (ANGGW) as early as December 2008, to implement the project on its own soil ${ }^{\mathbb{}}$. Today, Senegal is one of the most advanced countries in terms of actions taken.

The agency is under the authority of the Senegalese Environment and Sustainable Development Ministry. Beyond an annual financial contribution from the Senegalese government, it mainly depends on funding from the Global Environment Fund (GEF) through the Pan-African Agency of the Great Green Wall PAAGGW, the World Bank through the PDIDAS project (Senegal Sustainable and Inclusive Agribusiness Project, 2014-2020), the IUCN (International Union for Conservation of Nature) and from FAO (Pape Sarr, 2017, former ANGGW technical director, personal communication). The prerogatives of the ANGGW staff differ from those of the Water and Forestry foresters as their challenge is to fulfil the international reforestation commitments pledged by the State to the PAAGGW.

The way reforestation takes place has also changed since the initial ideas launched in 2002 in N'Djamena. Today, there is no longer talk of continuous

\footnotetext{
${ }^{7}$ The Senegalese Domaine National law, enacted in 1964, placed all non-registered lands in the national domain: the management and attribution of lands was entrusted to the municipalities, thus making it possible to maintain existing customary land management at village level.

${ }^{8}$ ANGGW was founded by Decree 2008-1521 dated 31/12/2008 (Serigne Mbodji (DPS/ANGGW), Presentation of GMV-Senegal, October 2012, 47 p).
} 
reforestation. As a result of local conflicts, cost of implementation, and expert opinions expressed that a wall-of-trees configuration was neither doable or desirable, the GGW has evolved into a network of plots, reforested and/or under deferred grazing with a system of enclosures. The plots form a mosaic along the GGW path, along with other activities under the GGW umbrella, such as communal women-run fruit and vegetable gardens, that provide diversification of local livelihoods (Goftner et al, 2019).

That said, reforestation is still a main GGW action. The reforestation process consists first in identifying, at the national level, the zones to be reforested, then seeking local consensus with the municipal authorities to delineate the plots to be placed under deferred grazing. This consensus must satisfy both the foresters, by identifying the target of 5,000 ha per year to be enclosed and reforested, and local stakeholders by choosing where plots are to be located (see sec. [.]).

The position of the ANGGW in this negotiation process is ambiguous, fluctuating between mistrust of local communities with regards to their awareness of environmental issues (Blundo, [2II4, §44) and the obligation to involve them under the National Domain law (Loi du Domaine National). In the field, this leads to more or less perceptible tensions between ANGGW staff and local communities. Be that as it may, local stakeholder uphold intimately entwined relationships with nature, including trees. It is therefore essential to understand the local communities' perception of their space and the natural resources located within it.

\subsection{Reforestation, territorialities and identity along the $G G W$}

The reforestation process is leading to the creation of new territorialities and control over resources by foresters. In Mali Gautier and Hautdidier (2012) stated that when it comes to forest protection: "the objectives of controlling people and resources through the creation of State territories interact with preexisting territorialities to produce new territoriality" (p.252). With these spaces come new subjectivity associated with their supporters/promotors (Dreyfus and 
Rabinow, 1982; Heyes, 2012). These new subjectivities are, for example, held by water and forestry agents who are, they themselves, shaped by their institutions. Their subjectivities are in tension with the subjectivities of the users of the territories in which they are asked to intervene.

The international desertification narrative is based on the fact that there is increasingly limited natural resources in the face of growing human demand (Benjaminsen, 2012). The ANGGW aligns with this narrative and results in a mutually-reinforced high-level interplay between the State and the international development community operating in the zone. This results in massive reforestation without taking into account the context and complexity of the social-ecological system diversity along the GGW path.

This high-level loop excludes local populations, i.e. the direct beneficiaries of GGW actions. When faced with reforestation schemes that alter their land use rights, the latter express themselves with great fervor, occasionally leading to conflict at the local level. This is even more true for transhumant pastoralists with mobile lifestyles; they are completed sidelined from negotiations and reforested plots are major obstacles to their mobility. Indeed, extensive livestock herding - with herds combining cattle, sheep and goats - is the primary land use (Ancey et al., 2008$)$. Large areas of land are needed to satisfy daily feed requirements (EIllis and Switt, 1988): consequently, establishing vast reforested and deferred grazing areas ${ }^{\mathbf{g}}$ hinders the freedom of movement of the herds and creates local mistrust towards massive reforestation projects such as the GGW.

In this paper, we illustrate the close links between reforestation practices associated with the GGW and national identity-building, and more specifically the roles played by foresters in these territories, ranging from that of environmental policemen and scouts, to representatives of the State in its outer reaches. However, it is important to point out a recent shift in the State foresters' roles towards those of development agents acting in closer collaboration with local

\footnotetext{
${ }^{9}$ The size of a deferred grazing plot reforested by the National Agency of the Great Green Wall in Senegal varies between 100 ha and 1,000 ha. Source : M. Mauclaire, 2017.
} 
populations, but today, these State foresters are still in the minority.

Since the 1964 land reform, although land ownership rights in Senegal still belong to the State, land management has been delegated to the municipalities. This implies that decisions in relation to land rights issues are shared among State authorities, municipalities and traditional authorities. These include the right to use and to delegate use (under traditional jurisdiction) and the right to ownership (inherited from French law currently under municipal jurisdiction) (Colin, 2008).

Despite decentralization policies, The State maintains a strong hold in these areas based on the following assumptions: $i$ ) local populations do not perceive the importance of the resources they use, ii) consequently they are incapable of managing the corresponding land, iii) the State must, therefore, act as a guarantor and judge of the rational use of natural resources. Withdrawing part of the Commons for reforestation purposes can be considered as a paternalistic emergence of the State subjectivities (Heyes, [20工2).

By employing large scale subtractive strategies, meaning the withdrawal of land use rights from local users ${ }^{\mathbb{m}}$, in areas that are usually managed by the municipalities. By withdrawing areas from traditional collective management by installing fences and gates, the State imposes new rules of land use, and distorts and delegitimizes the existing system of social relations.

\section{Materials and methods}

\subsection{Selection of four contrasted study sites}

In 2016, an interdisciplinary research team carried out an exploratory field mission along the entire 545-km long path of the GGW in Senegal. The aim was to observe and document, firsthand, the diversity and complexity of socialecological systems along the GGW path. Different landscape units along the

\footnotetext{
${ }^{10}$ For example, gathering fruit from trees does not interfere with grazing, while the installation of cultivated plots, protected by a fence, prohibits grazing.
} 
path were identified and photographed (9 photos of landscape units are provided in appendix Appendix A). Our on-site observations, combined with GIS data obtained from the National Agency for Land Use Planning Monitoring Center $\left[\right.$, and the IUCN ${ }^{\mathbb{W}}$, were used to select the four contrasted study sites described herein.

\subsection{Microgeography of lived space}

Two workshops were organized with local stakeholders at each site, one in tradition. During the workshops, the collective explanation of the 'lived' space

\footnotetext{
${ }^{11}$ In French, "l'Agence nationale pour l'aménagement du territoire" : http://wWw.anat.sn/, consulted in March 2021

${ }^{12}$ In French "Centre de suivie écologique" : https://www.cse.sn/ consulted in March 2021

${ }^{13}$ International Union for Conservation of Nature, https://www.iucn.org/, consulted in March 2021
} 


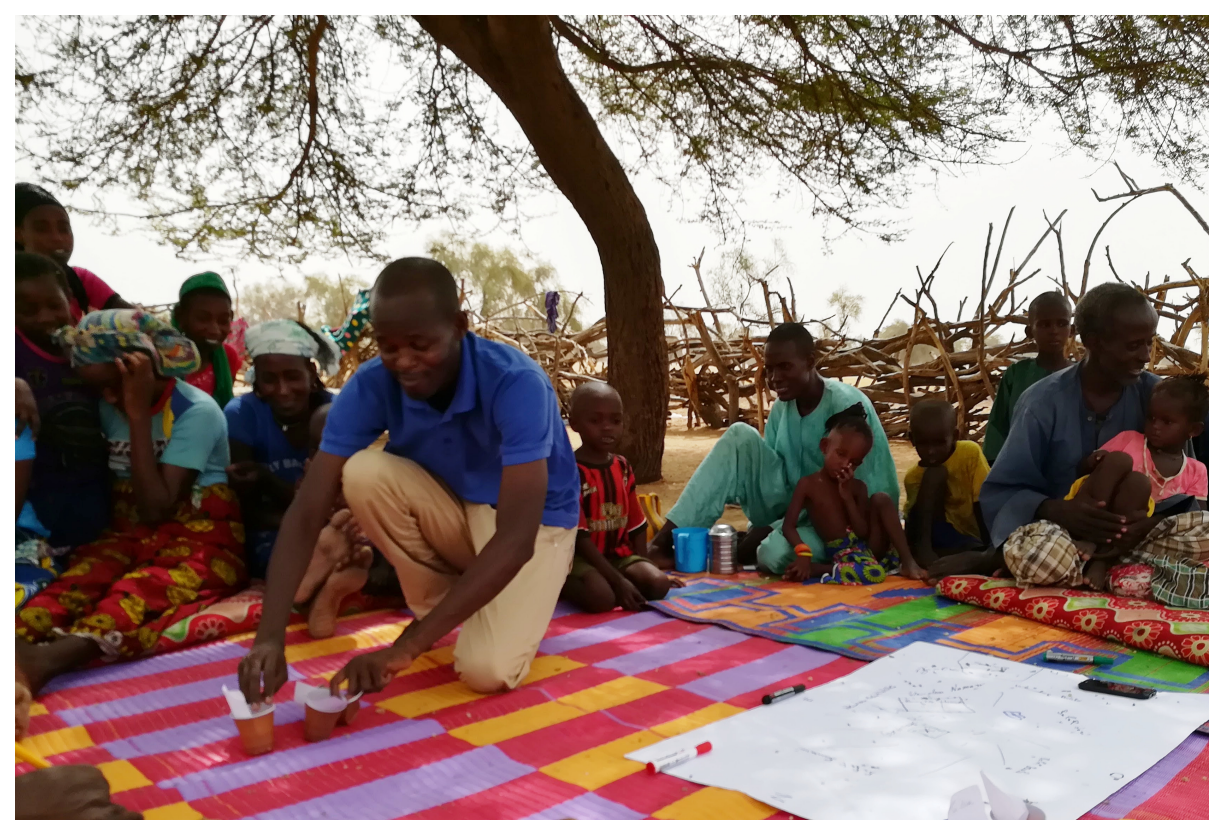

Figure 1: Photograph of a workshop carried out in Widou (October 2017). The facilitator (A. Ka) finished drawing the landscape elements on the mental map (bottom right of the picture). He is now setting up the landscape unit quantification process. He is holding containers in which a certain number of marbles will be placed, reflecting the participants' quantification of the importance of each landscape use for tree uses. Workshop participants are sitting around him, discussing and negotiating the results throughout the process. 
thus enabled us to access this collective frame of reference in terms of delimited spaces (Appendix Appendix B, stage S3 of the workshops). The quantification of trees and landscape unit uses (Appendix Appendix B, stages S4 and S5 of the workshops) enabled us to understand the importance of the territorialized resource.

The conceptions of the interdependence network of stakeholders explained by Di Méo (2008) are compatible with the definition of land tenure defended by Barrière and Barrière (ए996) and also Le Roy (2019): land encompasses two different realities the space itself and the resources located on that space. These authors consider land as a total social fact, based on the anthropology of the law. This led Le Roy (2014) to highlight the co-evolution of social practices and how societies relate to space throughout the world. Considering space from

235 the point of view of social geography, or considering land from the point of view of anthropology of the law, enabled us to grasp the relations between the inhabitants and their environment, notably the nature of their relations with spaces.

Our work is also aligned with the participatory mapping approaches described by Lardon et al. (2018) . In our approach, participatory mapping became an object of mediation (Cash et al, 20013) with the stakeholders, enabling them to evoke symbolically their relationship with the territory. Finally, the work by Sinare et al. (2016) in Burkina Faso and Jagoret et al. (2014) in Cameroon inspired the participatory and quantitative methodologies carried out in the workshops (see Appendix Appendix B).

\section{Results}

\subsection{Identification and description of the four contrasted study sites}

Based on observations from the exploratory mission and data collected from national and international agencies, we identified four socially and ecologically contrasted study sites along a west-east gradient along the GGW path: Sakal, Widou, Lougré Thioly and Ranérou (Fig. 『). Sakal and Ranérou are well- 


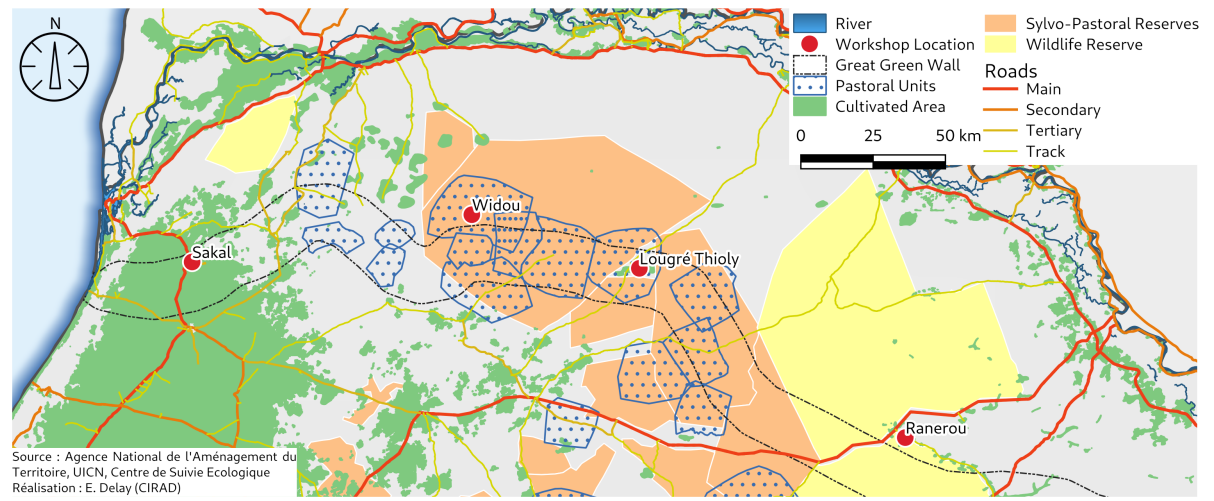

Figure 2: Map of the study sites. The theoretical path of the Great Green Wall in Senegal is shown by the dotted lines. The four study sites were located along it from West to East: Sakal, Widou, Lougré Thioly, Ranérou.

connected to the main road network (the latter, since 2017), while Lougré, and even more so Widou, are extremely remote.

Sakal is in an agricultural zone, whereas Widou and Lougré are in the sylvopastoral reserves which are vast spaces dedicated to pastoralism ("pastoral vocation" in French). In planning documents for the region, the notion of "vocation" implies specific bundles of laws and rights to preserve pastoralism (Colin, 2008; Le Roy, 2019). It does not exclude other practices, but addresses the responsibilities associated with crop production and protection differently. In pastoral areas, it is up to the farmers to keep the livestock out of the fields, whereas in agricultural areas, it is up to the herders to keep their animals out of the croplands. Ranérou is located within a Wildlife reserve which is itself incorporated into the Ferlo UNESCO "Man and Biosphere" (MAB) reserve. The MAB program promotes sustainable development based on the combined efforts of local communities, supported by local and scientific knowledge. This national and international label highlights locally managed natural resources and recognize the importance of society/nature interactions.

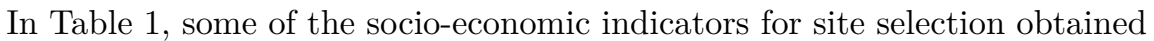
from municipality planning documents are indicated. The proportion of herders 

cators for the different sites are reported. Annual precipitations varies substantially: between $207 \mathrm{~mm}$ in the most arid municipality (Widou) to $378 \mathrm{~mm}$ in the least arid site (Ranerou). The annual mean temperature increases from West to East, Ranerou having the highest annual average. Finally, population growth annual growth between 2016 and 2017

Table 1: Socio-economic criteria from the different study sites. Data was taken from the planning documents of the municipalities.

\begin{tabular}{llll}
\hline Sites & main livelihood & herder activity $(\%)$ & $\begin{array}{l}\text { Main ethnic } \\
\text { groups* }\end{array}$ \\
\hline \hline Sakal & agriculture & 23 & $87 \%$ Wolof $10 \%$ Peulh \\
Widou & pastoralism & 77 & $83 \%$ Peulh $10 \%$ Maure \\
Lougré Thiouly & pastoralism & 57 & $87 \%$ Peulh $10 \%$ Maure \\
Ranérou & pastoralism & 43 & $93 \%$ Peulh
\end{tabular}

Table 2: Climatic indicators for the different study sites. Population growth data comes from "RGPHEA", precipitation was extracted from the CHRIPS database and temperatures from the national weather service.

\begin{tabular}{llll}
\hline Sites & $\begin{array}{l}\text { Average annual } \\
\text { temperature }\left({ }^{\circ} \mathrm{C}\right)\end{array}$ & $\begin{array}{l}\text { Average annual } \\
\text { precipitation }(\mathrm{mm})\end{array}$ & $\begin{array}{l}\text { Population growth }(\%) \\
2016-2017\end{array}$ \\
\hline \hline Sakal & 26.5 & 241 & 2.8 \\
Widou & 28.2 & 206 & 2.8 \\
Lougré Thiouly & 28.6 & 273 & 3.8 \\
Ranérou & 29.1 & 378 & 3.8
\end{tabular}

\subsection{Local uses of trees: between pasture and reforested plot}

A primary assumption was made in this study: that people living in contrasted social-ecological systems use trees and the landscape differently. The results from the workshop for the different landscape units and their tree-based uses are shown in Fig. [3. In this article, we specifically focus on two landscape units: pastures (bush) on the one hand, and reforested areas placed under deferred grazing by the GGW (reforested plot) on the other. 
At all four sites, the bush was the most useful landscape unit when considering the five tree uses (construction, firewood, fodder, food, medicine) combined, albeit to varying degrees. Reforested plots were also useful for providing provisioning ecosystem services (ES) at all the sites, with the exception of Sakal (the most western site and predominantly agricultural). However, it should be noted that when we refer to ecosystem services, this is our interpretation, as the workshop participants spoke of uses and did not specifically employ the term ES.

Another significant result is the relative importance of homesteads in providing ES. Currently, large-scale reforestation efforts are being invested in vast, isolated plots, but very few trees are being provided to families to plant around their homes. Our results suggest that this essential landscape unit should not be neglected as re-greening them could provide significant social benefits for local populations. Indeed, homesteads participate between 8 to $20 \%$ of the total lived space with respect to ES supply.

In Sakal, which is located outside the dedicated livestock herding zone, populations use the bush less compared to the other sites, even though it was used for all five tree ES. Construction remained the smallest use there, mostly likely because alternative building materials are readily available. The absence of tree use in reforested plots around Sakal also provided clues as to the different land uses that exist in predominantly agricultural vs pastoral zones. An enclosed plot in an agricultural area tends to signify to other potential users that the plot is privately owned and this is an accepted fact. This means that withdrawing a plot from collective use for reforestation in an agricultural zone would tend to upset human-environment relations to a lesser extent in an agricultural vs a predominantly pastoral zone.

\footnotetext{
${ }^{14} \mathrm{~A}$ provisioning service is any type of benefit to people that can be extracted from nature. Along with food, other types of provisioning services include drinking water, timber, wood fuel, natural gas, oils, plants that can be made into clothes and other materials, and medicinal benefits.
} 


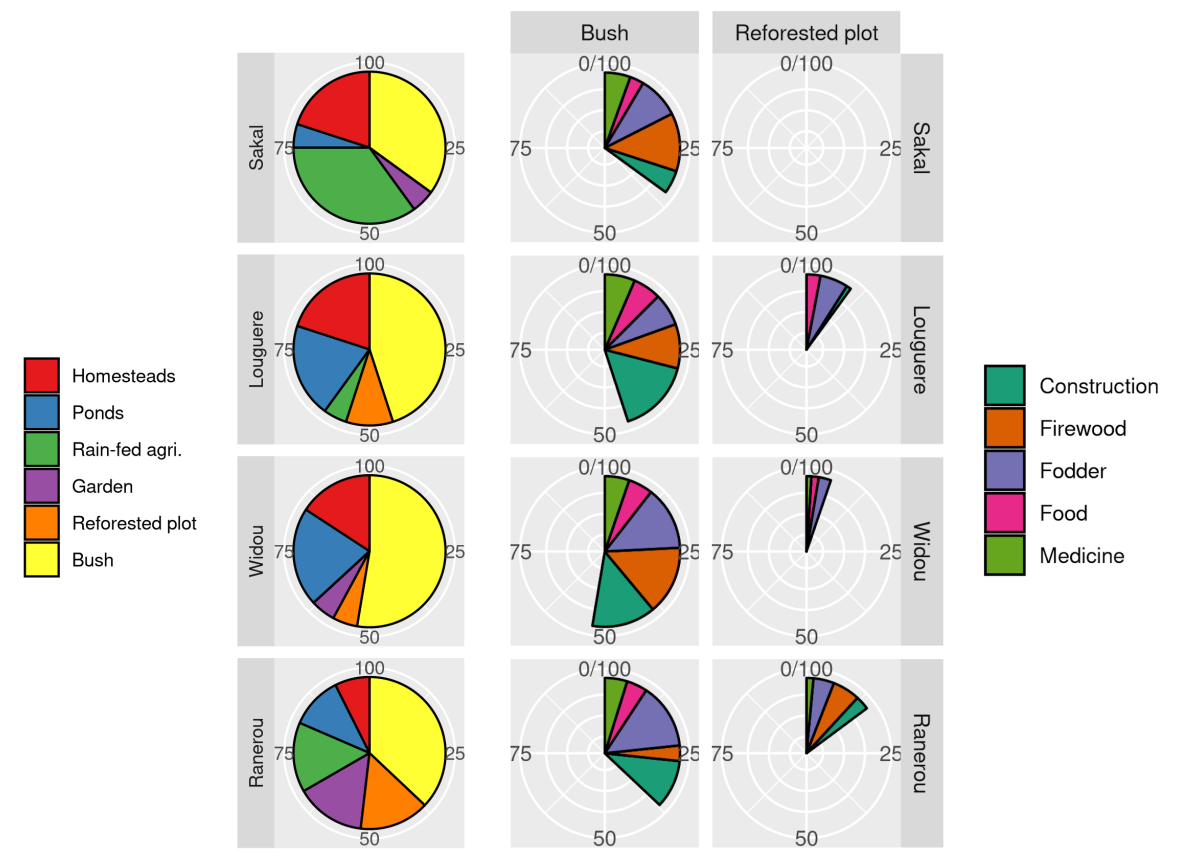

Figure 3: For each of the four study sites (left column), the quantification (middle and right columns) of tree uses per landscape unit and per usage type. First column on the left: relative importance of the landscape units identified as a function of all tree uses combined (quantification by the stakeholders at stage S4 of the workshops). Middle and right-hand columns (bush, reforested plot respectively): relative importance of each use identified by the stakeholders during stage S5 of the workshops. 
In the other three sites, the trees in the reforested plots were mostly used for fodder and to a lesser extent human food. The GGW plots are fenced, which allows the grass to grow without being grazed. This means that people can not only use the fodder from the trees, but they can also harvest grass for the animals that remain around the homesteads year round (Fig. ??). However, access to the plots is under the control of ANGGW authorities. Residents have to request for authorization from the local agency officer, an effective way of demonstrating who controls the space.

Together, the results presented herein demonstrate the undeniable consideration and attachment of local populations for trees, as well as their knowledge and dependence on natural resources. This dependency has a tendency to increase with the distance from State infrastructures and services (i.e. transportation, healthcare facilities). State infrastructure is more common in the western agricultural zones (e.g. Sakal), and becomes increasingly more sparse in the sites dedicated to pastoralism towards the east.

\subsection{Divergence national narratives and local needs}

From a local perspective, the GGW raises the issue as to whether the aspirations of local populations are sufficiently taken into account when designing on-the-ground actions. The GGW staff negotiates plot locations with rural communities. However, this tends to operate within a context of negative perception of pastoralism inherited from colonial times.

GGW actions must satisfy both foresters (representing state interests) and a variety of different stakeholders at the local level. Negotiations such as these 35 must allow the State to fulfill reforestation obligations promised at global scale, while at the same time, not comprising the land use that supports local needs. In reality, this is further complicated by the fact that local needs are not the same, for example, for a crop farmer or a livestock herder. Land tenure is also not the same in zones devoted to agriculture, where fenced plots are common to grow crops compared to pastoral zones where land is unfenced and used collectively and intermittently. This presumably implies fewer conflicts when edifying a 
GGW plot in Sakal (agricultural area), where land use is less dependent on open grazing for livestock compared to dedicated silvo-pastoral zones (Fig.[Z).

As indicated in Fig. [1, local populations in the four study sites are highly dependent on ES provided by trees. The local stakeholders are therefore in a tricky position. They recognize the importance of trees for their daily lives, but the current top-down solutions of large-scale reforested plots are unsatisfactory. Large-scale enclosures mean $i$ ) significant loss of readily available natural resources (i.e. everything inside the plot), and ii) drastic changes in transhumance trajectories if a plot is edified on a transhumance corridor. An interesting paradox is that local populations tend to perceive fencing positively, i.e. when they can decide when and where to install it and what to do within its boundaries, whereas they perceive it negatively when it is imposed on them in a top-down manner as it is, the case of large-scale reforestation plots. A fence in the landscape is not bad per se, it is more the way it is imposed in the landscape that is at the origin of the conflicts observed.

\section{Discussion}

The national and international discourse continues to support a vision of herders as the main drivers of land degradation, by rehashing once again the tragedy of the Commons. However, on the contrary, our results show to what extent local population perceive the importance of trees for their daily lives and livelihoods. This is particularly true in communities dominated by pastoral activities (Widou, Lougré, Ranerou).

Herein we provide an explanation as to what is perceived as overgrazing throughout the Sahel. It is less the result of local disrespect of nature and more a indirect repercussion of state interventions (i.e. multiplication of boreholes). Interventions are often poorly aligned with the belief systems and practices ingrained in pastoralism. One potential leverage point for land restoration could consist in supporting local populations towards the construction of a new Commons in reforestation protocols which would not result in the subtraction of large 
portions of land, but by promoting and reinforcing the capacity of communities to collectively manage natural resources including trees.

\subsection{From an old common pool resource perception to a new one}

Herein we propose to operationalize the theoretical framework as described

by Ostrom (19900). The Commons concept was widely legitimized by E. Ostrom in response to the wellknown example described by Hardin ([968). He described shared pastureland, for which he demonstrated that it is impossible for a natural resource to persist without private or centralized management. Ostrom ([1990) endeavoured to show that the example given by Hardin was a particular case linked to the nature of the regulation (open access), and that there is a wide range of conditions that favour collective management (Moritz et all, 2018). Taking the resource as the entry point enabled her to think about management rules and interactions, notably through the lens of the prisoner's dilemma and game theory, while remaining critical of the fixed nature of rules in theoretical approaches (Cárdenas and ()strom, [200).

The perception of space in the sense of Di Méo (2008) is compatible with the view of land tenure defended by Le Roy (피). Both these authors inform us about the types of representation and relations, formal or informal, that link societies and their environment(s). In other words, by enquiring into formal or informal relations with land, one also questions the way in which humansresource relations are mediated by space. Examining the status of the space makes it possible to investigate the social relations provided by the space itself. Considering land uses can also be considered as markers of certain appropriation regimes as legitimate as land titles. Paying attention to the social rules for the use of resources and spaces is referenced in many works in the Commons literature.

Along the lines of previous work on Commons, specific studies on land tenure by Le Roy (1996-2019) led to an update of conceptual frameworks of resource appropriation. Focused on relations between society and their environment, the Commons approach means investigating interdependency networks between 
humans and non-humans from a systemic angle (Descola, 2015). By drawing graphs of interactions between users and resources (as a representation for solidarity networks), it is possible to bring out key Commons, and thereby investigate appropriation regimes. The third principle of the French Land Tenure and Development Technical Committee (2017) states that a key Commons is "in a pragmatic approach [...] likely to have a significant knock-on effect on the resilience of other, interlinked Commons" (p.64).

\subsection{Overgrazing is paradoxically an issue of water abundance}

Water was traditionally the key Commons in the Sahelian pastoral zone of Senegal. The introduction of modern water access infrastructure (boreholes) helped to increase the productivity of previously underused spaces. However, water then changed from being a Common Good (in the form of temporary ponds) to being a Club Good (reserved for a small group of people). The multiplication of boreholes means that water access has gone from being natural to artificial. At the same time, , the densification of boreholes increases land degradation. This degradation, notably through overgrazing, is blamed on livestock herders, while the root cause remains the multiplication of boreholes, an ongoing public policy implemented throughout the Sahel. Walker (200.5) highlighted almost 15 years ago that "undermining these land users keen localized environmental knowledge and long histories of successful adaptation to sometimes harsh and unpredictable environments (e.g., Watt.s (ए98.3)), creating a situational rationality that could potentially force land users to degrade their environments in acts of desperate ecocide (Blaikie and Brooktield, [1.987)".

When considering conflicts between livestock herders and ANGGW staff, it intrinsically implies re-examining the roots causes of overgrazing. However, by mainly focusing on the fodder resource itself, the key Commons that has until now, serve as a "system regulator" is overlooked: water.

The installation of the borehole network in the Ferlo region in Senegal started during the colonial era (Foury, 1953), but accelerated in the mid-1990s (Fig. 四) and deeply disturbed the social regulation systems in place. Rangeland manage- 


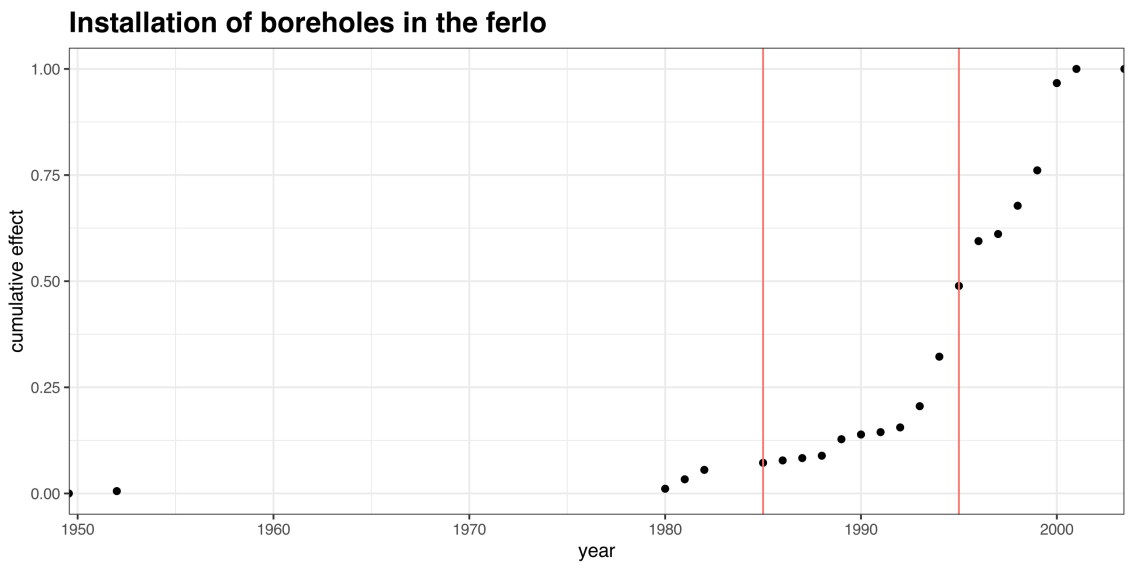

Figure 4: Cumulative frequency curve of borehole installation in the Ferlo region. The Ferlo is the silvopastoral zone located in northern Senegal where the three pastoral study sites are located. The vertical red lines are the class boundaries used in Fig. $\mathbf{0}$ (Source : DGPRE). The number of boreholes has increased over time, with a marked acceleration from the mid-1990s up until today.

ment was achieved through traditional collective rules of access to water points applied at the local level. Water was spatially and temporally rare, and was the key social regulator (Gonin, 2018$)$. This explains why overgrazing was inversely proportional to livestock watering capacity: when a pond dried up, the herds would naturally leave, which regulated the renewal of grazing areas. With the increasing number of state and international-funded boreholes throughout the

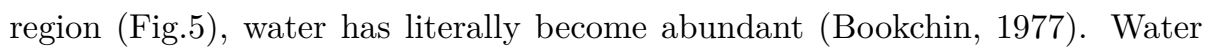
scarcity on which collective management was formerly based gradually saw the very environment under its control deconstructed. Indeed, as Sall (ए978) and Watts (1985) pointed out, the abundance of water and the overgrazing that this has provoked created a new social problem resulting in the disorganization of space.

In reality, this situation is a typical shift in the construction of modern water: according to (Linton, 200U), "Modern water is an intellectual achievement. [... ] ${ }_{445}$ Modern water reduces all water to this essential substance, this homogenous 


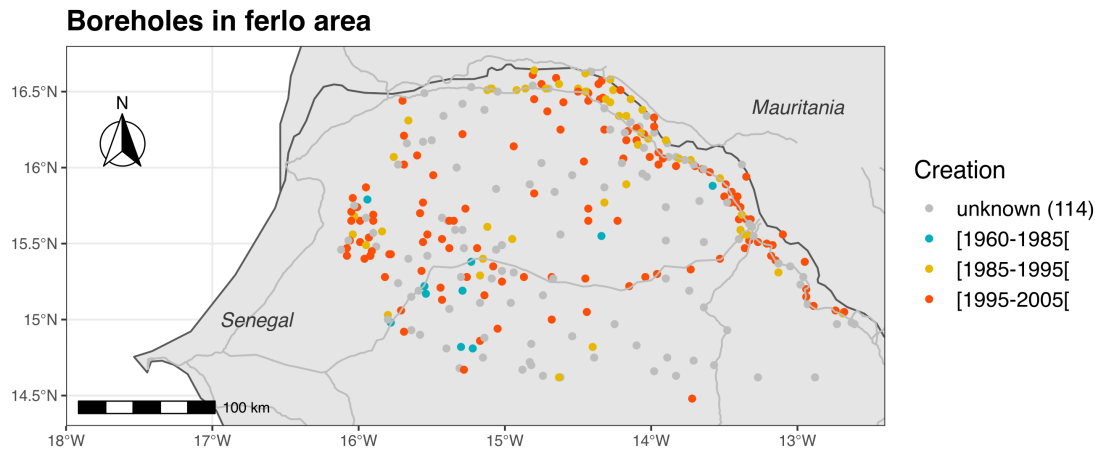

Figure 5: Map of boreholes in the Ferlo region of Senegal according to the Department of Water Resources Management and Planning (DGPRE). A fine mesh of boreholes throughout the region helps to explain the disappearance of pastoral zones that are accessible only during the rainy season.

chemical compound, both spatially and temporally" (p.18).

Considering modern water, meaning water as a chemical compound, helps to transform it into a manipulable and interchangeable object: this is currently the vision promoted by the State. The act of constructing a borehole therefore disregards the existing, traditional networks of relations between human (local populations) and non-human (plants, animals, etc.). It assumes that any water can replace any water. But this is not true; for local actors, water is part of a hydro-social cycle (Linton and Budds, 2014). It mobilizes rules of use inherited from ancestors, forms of attachment to the place of water (sacredness), it induces land use concerned by time, etc. There is no relationship of equivalence between the State's vision and the local visions of water in which the actors evolve. However, introducing a new water point (in the form of a borehole) immediately inscribes it in the hydro-social cycle of local actors. All the actions compatible with water in the traditional system (ponds) are transposed into the borehole system, however without the necessary accompanying measures. But this has consequences, the rules are not the same and everything must be renegotiated; 
from the use of water to the land use that depended on the traditional vision.

The failure to consider all of the intricate relationships with water has led to grazing resource degradation, by eliminating the markers of water rarefaction.

Green Wall in Senegal have been subjected to long-term monitoring. The results of these different field trials tend to show highly variable, albeit low, survival rates depending on the tree or shrub species and on the location of the plot.

\footnotetext{
${ }^{15}$ In 2019, the ANGGW as such was dissolved and englobed into the National Reforestation and Green Wall Agency that covers the entire Senegalese territory.
} 
For example, in Widou, survival rates for the most robust species were, at best, around $15 \%$ two years after transplantation from nurseries to field plots (Wade et al., (2018). In the same field trial, a spontaneous regeneration rate of $89 \%$ was observed for woody species when grazing was deferred, suggesting that, for regreening, natural regeneration is a viable alternative to reforestation. In other areas in the Sahel, farmer assisted natural regeneration, which involves farmers managing and protecting the growth of trees and shrubs that regenerate naturally in their fields (Reij and Winterbottom, 2015), has also proven extremely effective in increasing plant biomass production on a large-scale basis.

Natural regeneration of woody species is not new in Africa (Reij et al., 2001.9; Reij and Winterbottom, 2015), but the results of the GGW experimental plots in Senegal pave the way for new solutions in pastoral zones. These solutions need to enable young plants to become established perennially, without being hindered by herd movements in space and over time. One solution was suggested to us by livestock farmers around Widou (personal communication, 2017): these farmers suggested they should be provided with fencing so that they could close off areas for a limited time, such as three years; once the woody species were established, the livestock herders would move the fences elsewhere. For them, the fact of freely choosing the location of the plots and their size radically contrasted with current ANGGW practices. Likewise, they would no longer need to ask for permission to seek fodder in those areas. This change in practice would be far better adapted to local land management (d'Aquino and Bah, 20133; Scoones, 1994) than that of permanent enclosures of large reforested plots commonly found along the GGW.

In this context, it is worth citing the six steps of Reij and Winterbottom (खण15) described in their report "Scaling up Regreening: Six Steps to Success. Practical Approach to Forest and Landscape Restoration": "1- Identify and analyse existing regreening successes; 2- Build a grassroots movement for regreening; 3- Address policy and legal issues to enable conditions for regreening; 4- Develop and implement a communication strategy; 5- Develop or strengthen agroforestry value chains; and 6- Expand research activities" (p. 4). Regarding 

ing regreening practices. For step 2, voluntary champions of the initiative, to whom wire fencing could be distributed, for example, have already been identified. To address the political and legal issues (step 3) that deferred grazing established by the livestock farmers would entail, existing collectives could be called upon, such as the "Land Use and Allocation Plan" committees (POAS, which are land occupation agreements signed between local authorities and the State): they can decide on the temporary allocation of areas for deferred grazing. Lastly, with a view to disseminating practices and developing value chains (steps 4 and 5), the plots under deferred grazing could also serve as a forage reserve to feed herds at the end of the rainy season, prior to transhumance. Some collective harvesting rules could be negotiated there and introduced. This entire process would have to be monitored by research teams to identify inflection points (step 6) and help to disseminate these practices.

\section{Conclusion}

This study allowed us to highlight the diversity and specificities of tree use in four contrasting sites along the GGW in Senegal. This diversity demonstrates not only the dependence of local communities on trees for their livelihoods, but also a sense of attachment to nature. Yet these values are not commonly recognized in national and international narratives. Our results shed light on this fundamental misunderstanding between decision-makers and local actors, each with their different relationship with natural resources and to nature itself.

In Senegal, the State, by way of the ANGGW, is introducing reforested plots with deferred grazing in the Sahelian pastoral zone. It is thus pursuing its crusade to maintain control over these spaces located in its outlying territories. livestock herders as they are compatible with traditional water use methods, this is yet to be the case for the standards and values promoted around reforestation.

If the reforestation objectives fixed by the State and the international com- 
munity to combat desertification are to be achieved, it will be necessary to facilitate the constitution of a pastoral Commons. This could involve setting up "assisted natural regeneration" initiatives that are co-constructed with PAAGGW, ANGGW staff and local stakeholders. Allocating wire fencing for deferred grazing could be done in return for a commitment over a limited time to prevent livestock from entering the plot. Thus, the area does not fall into a land titling regime, but remains accessible to everyone over a long period, while being withdrawn from direct grazing the time that it is necessary for the trees and shrubs to regenerate. Fodder could also be cut there to feed animals during the dry season.

As of early 2021, a new UN platform, the GGW Accelerator, has been launched to coordinate the activities and projects of international donors and research and development teams around the GGW initiative. The creation of this platform constitutes a window of opportunity for donors and partner countries of the project: "The Accelerator will support the Great Green Wall countries to adopt a more comprehensive approach to rural development, including improving the production systems that underpin livelihoods of smallholder farmers and pastoralist communities [...]" Within this initiative, our results show that for States and national agencies involved in the GGW project, changes are needed in governance of reforestation projects, for example by delegating more power at the community level. At the same time, external stakeholders including international donors, development agents and researchers must be aware, despite good intentions, of their potential negative impact on the system, so as to not find themselves supporting paradoxical solutions.

Finally, while taking on a Commons approach could lead to local empowerment, the shift from State management to community-based management could also be seen as a way for the State to reduce its expenditure. However, mo-

\footnotetext{
${ }^{16}$ UNCCD, 2021. The Great Green Wall Accelerator. https://www.unccd.int/ actionsgreat-green-wall-initiative/great-green-wall-accelerator, consult 13th of July.
} 
bilizing a Commons approach should not be perceived as a retreat from State prerogatives. It is more about delegating decision-making and action to those who are most directly concerned by the issues at the appropriate scales of intervention.

\section{Acknowledgements}

We are grateful for the generous financial support from the French Agence Nationale de la Recherche for the FUTURE-SAHEL program (ANR-15-CE030001). This work was co-funded by the Labex DRIIHM and the French program B "Investissements dAvenir" (ANR-11-LABX-0010). We would like to thank Jean-Luc Peiry (University of Clermont Auvergne) for his scientific support. We also warmly thank Karine Ginoux and Sophie Drame who always ensure that our field missions run as smoothly as possible from an administrative and logistic standpoint. We thank the Senegalese Directorate of Water, Forestry, Hunting and Soil Conservation (DEFCCS) for logistic support during the field missions. Thanks also to Cecile Fovet Rabot for her critical proofreading since the first lines of the manuscript. Thanks to Peter Bigins and Daphne Goodfellow for the translation. Finally, a tremendous thanks to all of the local workshop participants who kindly spent time discussing development in the Ferlo with us.ă

\section{References}

Ancey, V., Ickowicz, A., Corniaux, C., Manoli, C., Magnani, S., 2008. Stratégies pastorales de sécurisation chez les Peuls du Ferlo (Sénégal). Journal des africanistes , 105-119URL: http://journals.openedition.org/ africanistes/2280. iSBN: 9782908948318 Number: 78-1/2 Publisher: Société des africanistes.

Aubréville, A...A., 1949. Climats : forêts et désertification de l'Afrique tropicale. Société d'éditions géographiques, maritimes et coloniales. Paris. 
Barrière, O., Barrière, C., 1996. Approches environnementales : systèmes fonciers dans le delta intérieur du Niger : de l'implosion du droit traditionnel à la recherche d'un droit propice à la sécurisation foncière, in: La sécurisation foncière en Afrique: pour une gestion viable des ressources renouvelables. Karthala, Paris. Economie et développement. URL: https://horizon.documentation.ird.fr/exl-doc/pleins_ textes/divers15-07/010065117.pdf.

Benjaminsen, T.A., 2012. Changements climatiques et conflits au Sahel, in: Gautier, D., Benjaminsen, T.A. (Eds.), Environnement, discours et pouvoir : L'approche Political ecology. Quae éditions, Versailles.

Benjaminsen, T.A., Kepe, T., Bråthen, S., 2008. Between Global Interests and Local Needs: Conservation and Land Reform in Namaqualand, South Africa. Africa 78, 223-244. URL: https://www.cambridge.org/core/journals/africa/article/abs/ between-global-interests-and-local-needs-conservation-and-land-reform-in-namaqualand-sou 1E2430A4A96FOC353A9EAA088F/EBTAF\#, doi:10.3366/E0001972008000144. publisher: Cambridge University Press.

Bernard, C., 1993. Les débuts de la politique de reboisement dans la vallée du fleuve Sénégal (1920-1945). Outre-Mers. Revue d'histoire 80, 4982. URL: https://wWw.persee.fr/doc/outre_0300-9513_1993_num_80_ 298_3081, doi:10.3406/outre.1993.3081. company: Persée - Portail des revues scientifiques en SHS Distributor: Persée - Portail des revues scientifiques en SHS Institution: Persée - Portail des revues scientifiques en SHS Label: Persée - Portail des revues scientifiques en SHS Publisher: Société française d'histoire d'outre-mer.

Bernus, E., 1974. Possibilites et limites de la politique d'hydraulique pastorale dans Ie Sahel nigerien. Cahiers ORSTOM.Série Sciences Humaines 11, 119-126. URL: https://horizon.documentation.ird.fr/exl-doc/ pleins_textes/pleins_textes_4/sci_hum/04162.pdf. 
Blaikie, P., Brookfield, H. (Eds.), 1987. Land degradation and society. Réedition 2016 ed., Methuen, London ; New York. OCLC: 953886270.

Blundo, G., 2014. Les Eaux et Forêts sénégalais entre participation et militarisation. Ethnographie dune réforme. Anthropologie \& développement , 185223URL: http://journals.openedition.org/anthropodev/481, doi:10. 4000/anthropodev. 481 .

Blundo, G., Sardan, J.P.O.d., 2001. La corruption quotidienne en Afrique de l'Ouest. Politique africaine Nř 83, 8-37. URL: https://www.cairn. info/revue-politique-africaine-2001-3-page-8.htm. publisher: Editions Karthala.

Bookchin, M., 1977. Post-scarcity anarchism. Number No. 071 in Black Rose Books. 2. ed ed., Black Rose Books, Montréal. OCLC: 255623588.

Cash, D.W., Clark, W.C., Alcock, F., Dickson, N.M., Eckley, N., Guston, D.H., Jäger, J., Mitchell, R.B., 2003. Knowledge systems for sustainable development. Proceedings of the National Academy of Sciences 100, 80868091. URL: http://www.pnas.org/content/100/14/8086, doi:10.1073/ pnas. 1231332100.

Colin, J.P., 2008. Disentangling intra-kinship property rights in land: a contribution of economic ethnography to land economics in Africa. Journal of Institutional Economics 4, 231-254. URL: https://wWw.cambridge.org/ core/product/identifier/S1744137408000970/type/journal_article, doi:10.1017/S1744137408000970.

Committee, L.T.a.D.T., 2017. The opportunities and challenges presented by a land-based commons approach. Technical Report. MEAE and AFD. Paris (France). URL: http://www.foncier-developpement.fr/wp-content/ uploads/Land-based-commons-approach.pdf.

Cárdenas, J.C., Ostrom, E., 2001. What do people bring into the game? How 
norms help overcome the tragedy of the commons. 4eme Journées dEconomie de lEnvironnement de Toulouse .

d'Aquino, P., Bah, A., 2013. A bottom-up participatory modelling process for a multi-level agreement on environmental uncertainty management in West Africa. Journal of Environmental Planning and Management 56, 271-285. URL: https://doi.org/10.1080/09640568.2012. 665361, doi:10.1080/09640568.2012.665361. publisher: Routledge_eprint: https://doi.org/10.1080/09640568.2012.665361.

Descola, P., 2015. Par-delà nature et culture. Folio, Paris.

Di Méo, G., 2008. Une géographie sociale entre représentations et action. Montagnes méditerranéennes et developpement territorial , 13-21URL: nttps: 7/halshs.archives-ouvertes.fr/halshs-00281573.

Dia, A., Duponnois, R., 2013. Le projet majeur africain de la Grande Muraille Verte: concepts et mise en oeuvre. IRD Editions.

Dreyfus, H.L., Rabinow, P., 1982. Michel Foucault : Beyond Structuralism and Hermeneutics. 2nd revised edition ed., University of Chicago Press, Chicago.

Elie, M., 2015. Formulating the Global Environment: Soviet Soil Scientists and the International Desertification Discussion, 196891. The Slavonic and East European Review 93, 181-204. URL: https://wWw.jstor.org/stable/ 10.5699/slaveasteurorev2.93.1.0181, doi:10.5699/slaveasteurorev2. 93.1.0181. publisher: [Modern Humanities Research Association, University College London, School of Slavonic and East European Studies, University College London].

Ellis, J.E., Swift, D.M., 1988. Stability of African Pastoral Ecosystems: Alternate Paradigms and Implications for Development. Journal of Range Management 41, 450. URL: https://www.jstor.org/stable/3899515?origin= 
Foury, P., 1953. Politique forestière au Sénégal. Bois et Forêts des Tropiques 30, 8-21. doi:https://doi.org/10.19182/bft1953.30.a18501.

Frémont, A., 1976. La région, espace vécu. Réedition de 2009 ed., Flammarion.

Gautier, D., Hautdidier, B., 2012. Political ecology et émergence de territorialités inattendues : lexemple de la mise en place de forêts aménagées dans le cadre du transfert dautorité de gestion au Mali, in: Gautier, D., Benjaminsen, T.A. (Eds.), Environnement, discours et pouvoir : L'approche Political ecology. Quae éditions, Versailles, pp. 241-257.

Goffner, D., Sinare, H., Gordon, L.J., 2019. The Great Green Wall for the Sahara and the Sahel Initiative as an opportunity to enhance resilience in Sahelian landscapes and livelihoods. Regional Environmental Change 19, 1417-1428. URL: http://link.springer.com/10.1007/s10113-019-01481-z, doi:10. 1007/s10113-019-01481-z.

Gonin, A., 2018. Le foncier pastoral au Sahel, des mobilités fragilisées. Bulletin de l'Association de géographes français 95, 175-186. URL: http://journals. openedition.org/bagf/3049, doi:10.4000/bagf.3049.

Guay, K., Beck, P.S.A., Goetz, S.J., 2015. Long-Term Arctic Growing Season NDVI Trends from GIMMS 3g, 1982-2012. Technical Report. Oak Ridge National Laboratory. Oak Ridge, Tennessee, USA. URL: http://dx.doi. org/10.3334/ORNLDAAC/1275.

Hardin, G., 1968. The Tragedy of the Commons. Science 162, 1243-1248. URL: http://www.sciencemag.org/content/162/3859/1243, doi:10.1126/science.162.3859.1243.

Heyes, C.J., 2012. Subjectivity and power, in: Taylor, D. (Ed.), Michel Foucault. Acumen Publishing Limited, Durham, pp. 159-172. URL: https:// WwW.cambridge.org/core/product/identifier/CB09781844654734A020/ type/book_part, doi:10.1017/UP09781844654734.012. 
Jagoret, P., Kwesseu, J., Messie, C., Michel-Dounias, I., Malézieux, E., 2014. Farmers assessment of the use value of agrobiodiversity in complex cocoa agroforestry systems in central Cameroon. Agroforestry Systems 88, 983-1000. URL: https://link.springer.com/article/10.1007/ s1()4b/-014-96.98-1, doi:10.1007/s10457-014-9698-1.

Lardon, S., Caron, P., Bronner, A.C., Giacommel, G., Raymond, R., Brau, F., 2008. Jeu collaboratif de construction de territoire: interagir par les représentations spatiales. Revue internationale de géomatique 18, 507-530. URL: http://wWw.emse.fr/site/SAGE02007/CDROM/CQFD01.pdf.

Le Houérou, H.N., 1996. Climate change, drought and desertification. Journal of Arid Environments 34, 133-185. URL: http://wWW.sciencedirect.com/ science/article/pii/S0140196396900993, doi:10.1006/jare.1996.0099.

Le Roy, E., 2019. Pourquoi et comment la juridicité des communs sest-elle imposée dans nos travaux fonciers ? Récit dune initiation. Number 8 in Regards sur le foncier. 1 ed., Comité technique ń Foncier \& développement ż, AFD, MEAE, Paris.

Linton, J., 2010. What is Water?: The History of a Modern Abstraction. UBC Press. Google-Books-ID: vjwJoObk4zAC.

Linton, J., Budds, J., 2014. The hydrosocial cycle: Defining and mobilizing a relational-dialectical approach to water. Geoforum 57, 170-180. URL: https://wWw.sciencedirect.com/science/article/pii/ S0016/18b13002327, doi:10.1016/j.geoforum.2013.10.008.

Maraseni, T.N., Bhattarai, N., Karky, B.S., Cadman, T., Timalsina, N., Bhandari, T.S., Apan, A., Ma, H.O., Rawat, R.S., Verma, N., San, S.M., Oo, T.N., Dorji, K., Dhungana, S., Poudel, M., 2019. An assessment of governance quality for community-based forest management systems in Asia: Prioritisation of governance indicators at various scales. Land Use Policy 81, 750-761. URL: https://wWW.sciencedirect.com/science/article/pii/ S026483//1831038X, doi:10.1016/j.landusepol.2018.11.044. 
Moritz, M., Behnke, R., Beitl, C.M., Bird, R.B., Chiaravalloti, R.M., Clark, J.K., Crabtree, S.A., Downey, S.S., Hamilton, I.M., Phang, S.C., Scholte, P., Wilson, J.A., 2018. Emergent sustainability in open property regimes. Proceedings of the National Academy of Sciences 115, 12859-12867. URL: https://www.pnas.org/content/115/51/12859, doi:10.1073/pnas. 1812028115. publisher: National Academy of Sciences Section: Perspective.

Ostrom, E., 1990. Governing the commons: The evolution of institutions for collective action. Cambridge university press. URL: http://books.google.com/books?hl=en\&lr=\&id=4xg6oUobMz4C\&oi=fnd\&

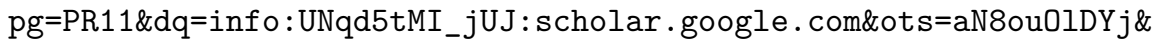
sig=ITmHzigIRcsiuqkbdrGD2nCea4k.

Reich, P.F., Numbem, S.T., Almaraz, R.A., Eswaran, H., 2001. Land resource stresses and desertification in Africa, in: Response to Land Degradation. CRC Press, pp. 101-116.

Reij, C., Tappan, G., Smale, M., 2009. Agroenvironmental transformation in the Sahel: Another kind of" Green Revolution". volume 914. Intl Food Policy Res Inst.

Reij, C., Winterbottom, R., 2015. Scaling up Regreening: Six Steps to Success. URL: https://www.wri.org/publication/ scaling-regreening-six-steps-success.

Reynolds, J.F., Smith, D.M.S., Lambin, E.F., Turner, B.L., Mortimore, M., Batterbury, S.P.J., Downing, T.E., Dowlatabadi, H., Fernandez, R.J., Herrick, J.E., Huber-Sannwald, E., Jiang, H., Leemans, R., Lynam, T., Maestre, F.T., Ayarza, M., Walker, B., 2007. Global Desertification: Building a Science for Dryland Development. Science 316, 847851. URL: https://www.sciencemag.org/lookup/doi/10.1126/science. 1131634, doi:10.1126/science.1131634.

Sall, A., 1978. Quel aménagement pastoral pour le Sahel ? Revue Tiers Monde 70 19, 161-169. URL: https://www.persee.fr/doc/tiers_0040-7356_1978_ 
num_19_/3_2185, doi:10.3406/tiers.1978.2785. publisher: Persée - Portail des revues scientifiques en SHS.

Scoones, I., 1994. Living with uncertainty: new directions in pastoral development in Africa. ITDG Publishing, London.

Sinare, H., Gordon, L.J., Enfors Kautsky, E., 2016. Assessment of ecosystem services and benefits in village landscapes A case study from Burkina Faso. Ecosystem Services 21, 141-152. URL: http://linkinghub.elsevier.com/ retrieve/pii/S2212041616302170, doi:10.1016/j.ecoser.2016.08.004.

UNCCD, 1994. Implementation of the United Nations Convention to Combat Desertification in Those Countries Experiencing Serious Drought and/or Desertification, Particularly in Africa : resolution / adopted by the General Assembly, in: U.N. Doc. A/AC.241/27, 33 I.L.M.1328, United Nations, 1994)., p. 58. URL: https://www.unccd.int/sites/default/files/ relevant-links/2017-01/English_0.pdf.

Wade, T.I., Ndiaye, O., Mauclaire, M., Mbaye, B., Sagna, M., Guissé, A., Goffner, D., 2018. Biodiversity field trials to inform reforestation and natural resource management strategies along the African Great Green Wall in Senegal. New Forests 49,341-362. URL: https://doi.org/10.1007/ s110b6-017-9623-3, doi:10.1007/s11056-017-9623-3.

Walker, P.A., 2005. Political ecology: where is the ecology? Progress in Human Geography 29, 73-82. URL: http://journals.sagepub.com/doi/10.1191/ 0309132505ph530pr, doi:10.1191/0309132505ph530pr.

Watts, M., 1983. Silent violence: food, famine, and peasantry in northern Nigeria. Geographies of justice and social transformation. re-edition 2013 ed., University of Georgia Press, Athens.

Watts, M.J., 1985. Social Theory and Environmental Degradation, in: Gradus, Y. (Ed.), Desert Development: Man and Technology in Sparselands. Springer Netherlands, Dordrecht. The GeoJournal Library, pp. 14- 
32. URL: https://doi.org/10.1007/978-94-009-5396-3_2, doi:10.1007/

\section{Appendix A. Landscape units}

Prior to workshops, taking a landscape ecology approach, we identified nine major landscape units existing along the GGW in Senegal (Fig. 『). These photos were shown to the stakeholders one-by-one during the workshops, in 805 phase S2 (see Appendix Appendix B), while creating the mental maps described below. 


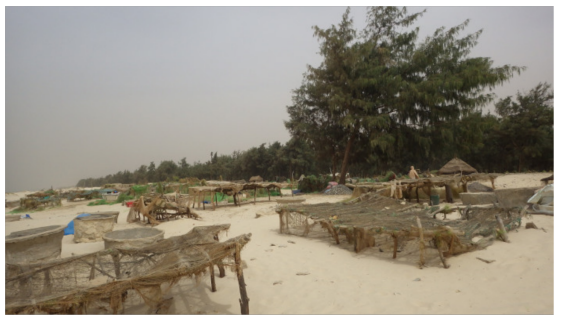

(a)

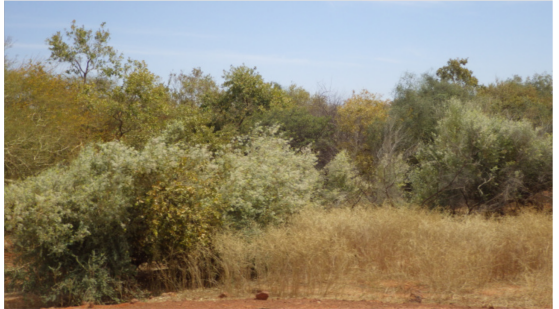

(c)

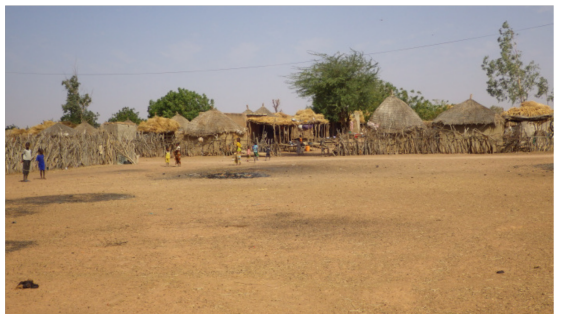

(e)

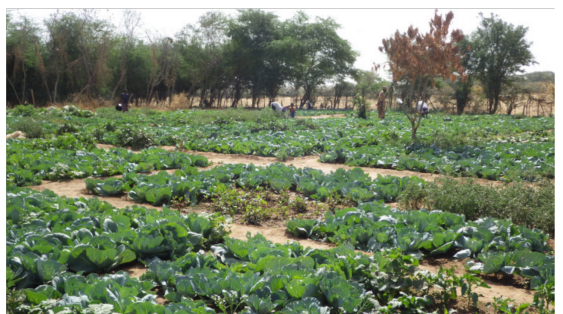

(g)

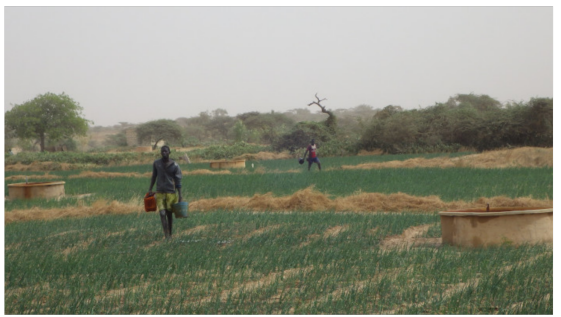

(b)

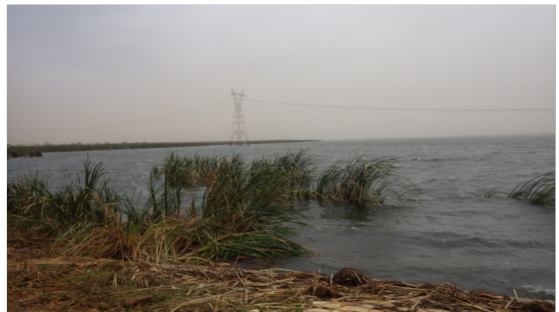

(d)

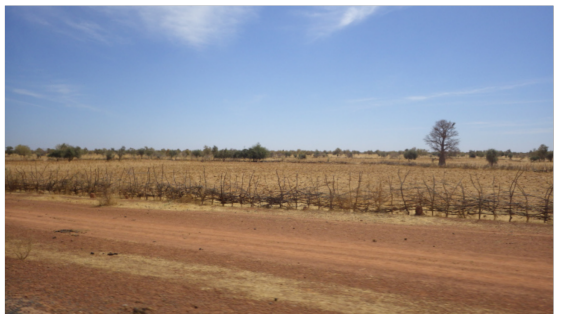

(f)

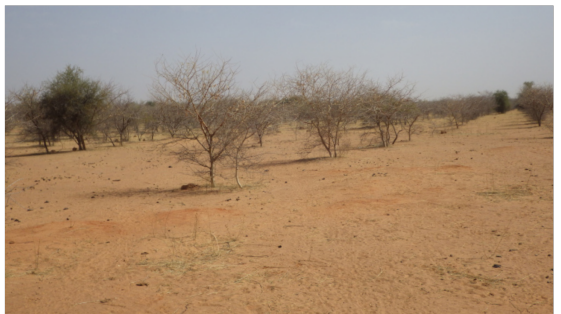

(h)

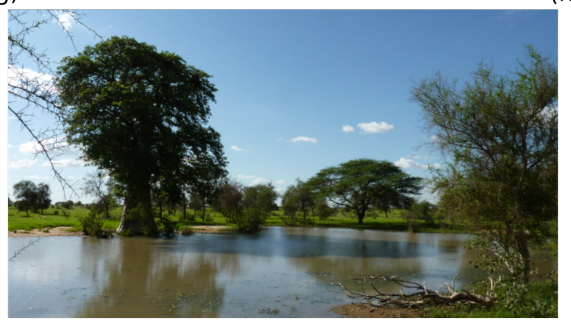

(i)

Figure A.1: Photos shown to the stakeholders during the workshops: a) Atlantic coast, b) irrigated agriculture, c) sparse bush, d) shore of Lake Guiers, e) homesteads, f) rainfed agriculture, g) multi-purpose garden, h) Great Green Wall reforested plot, i) pond. 


\section{Appendix B. Workshop methodology}

For each workshop (two workshops were held at each of the four sites, one in the centre of the village, the other on the outskirts). Our research team three languages used (French, Pulaar, Wolof) and who was responsible for the smooth operation of the workshops; two translators, one translating from the stakeholders language into French, the other taking notes; and at least two Frenchspeaking researchers who followed the discussion and quantification process. Each workshop had 15 participants. Each workshop took place in seven stages:

- Stage S0 - This first stage served to place the stakes in context and explain them. It enabled the stakeholders to feel confident enough to answer the questions as honestly as possible. We made a link between the work of the National Agency of the Great Green Wall (ANGGW) and the work of the project covering our own (XXXX project references), emphasizing the potential contributions of workshop outputs for future GGW natural resource management decisions.

- Stage S1 - We began by presenting the space on a white A0 sheet of paper. The workshop leader marked out the space inhabited by the populations using spatial landmarks and the points of the compass (North, South, East, West) (Frémont, 1976). To make their collective mental map, the participants were then invited to indicate the location of, for example water points, hills or roads. The delimited area was considered as their daily living space, i.e. the places they might move around throughout the day.

- Stage S2 - All the photos of the landscape spatial units taken during the exploratory field mission (Appendix Appendix A) were shown to the participants to whom two questions were asked: i) Do you recognize the spatials units? ii) Does this spatial unit exist in the space you mapped 
out in stage S1 as being a part of your daily living space? If spatial units appeared to be missing they were discussed and added if necessary. In the following four stages (S3 to S6), only spatial units identified by the participants were considered for further analysis.

- Stage S3 - Each spatial unit was drawn on the map, with the help of the landmarks established in stage S1. Three quantification stages then followed (S4, S5). Each consisted, for the stakeholders, in agreeing on the relative importance of each spatial unit. A number of tokens were distributed according to the importance that the group of stakeholders collectivelyassigned to the landscape unit in question. As the number of tokens was arbitrarily fixed at ten for each stage, at the end of the workshop we were able to weigh each category of tree usage according to each landscape unit.

- Stage S4 - We asked the stakeholders to quantify the relative importance of each landscape unit according to their use of trees. For this purpose, the group of participants used ten tokens distributed in the different units. This collective distribution was done by seeking a consensus in the group, which necessarily led to an exchange of opinions.

- Stage S5 - For each landscape unit, we proposed the five ecosystem ser855 vices, or uses (food, fodder, construction, medicine, firewood). We asked the participants to quantify the importance of each in relation to their use of trees. 